\title{
The Myth of the Totalitarian Leader in George Orwell's 1984 and Ismail Kadare's The Palace of Dreams
}

\author{
Ma. Ervin Xhinaku \\ English Lecturer, "Fan S. Noli” University, Korca, Albania; exhinaku@yahoo.com \\ Dr. Olsa Pema \\ English Lecturer, "Fan S. Noli” University, Korca, Albania; olsa.pema@yahoo.com
}

Doi:10.5901/mjss.2015.v6n6s2p150

\begin{abstract}
Kadare's allegorical anti-totalitarian novels are often compared by literary critics to George Orwell's classical dystopian satire, 1984. What this often-made but rarely-explored comparison suggests is that there is an essential affinity between the totalitarian world presented in Kadare's anti-totalitarian novels and the famous nightmarish dystopia of Orwell's 1984. The express aim of the present study is to isolate one of the key building blocks in Orwell's and Kadare's conceptions of the overall structure of totalitarianism - the great leader who stand atop the rigid hierarchy of the totalitarian state - and analyse the role it plays in the totalitarian scheme of things. With this aim in view, we have submitted the character of Big Brother from Orwell's 1984 to a comparative analysis with the character of the Sultan from Kadare's most representative anti-totalitarian novel, the allegorical Palace of Dreams. The close textual analysis of the way the two characters artistically function in the respective novels, and of their ideological significance for the totalitarian worlds described in them, shows that they bear a marked resemblance to each-other. Essentially, both Big Brother and the Sultan are conceived as archetypal characters who, beyond any more immediate connections to particular historical personages, stand for the totalitarian leader as such. Furthermore, as the results of our analysis show, their mythical conception in the two novels highlights the representation of the figure of the great leader in the minds of totalitarian men as an almost godly being with attributes more divine than human.
\end{abstract}

Keywords: myth, god, totalitarian, archetype

\section{Introduction}

Central to both Kadare's and Orwell's vision of totalitarianism, as presented respectively in 1984 and the Palace of Dreams, is the foundational myth of the Great Leader whose wisdom and might are believed to sustain the whole totalitarian universe. In this study we have submitted the two novels to a close comparative examination, with the express object of finding out how that myth is constructed and the role it plays in the totalitarian worlds created by the two writers. Besides being firmly grounded on the close literary analysis of the texts themselves, our interpretations have made use of concepts and categories belonging to a variety of disciplines, both literary and otherwise, which, from different angles, help to throw light on the issues under consideration.

It should be pointed out right from the start that, far from being a rare aberration with no inherent relationship to the fundamental nature the political systems described in the two novels, the near apotheosis of the leader as presented by Orwell in 1984 and Kadare in the Palace of Dreams constitutes a fundamental feature of totalitarianism as such. This identity of conceptions as to the nature of totalitarian leadership is made all the more evident by the fact that 1984 and The Palace of Dreams share a marked resemblance in the way the myth of the great leader is constructed. The individual characteristics of the leader as a person, beyond his social and political function, are, actually, barely touched upon by the two writers. Highly significant in this context is the suggestion in 1984 that Big Brother might not even exist in flesh and blood, and the fact that in The Palace of Dreams the Ottoman sultan is never referred to by his proper name. The reader, as a matter of fact, at no time ever directly encounters Orwell's Big Brother or Kadare's Sultan. Their sinister presence, however, looms threateningly behind almost everything that is said and done in the two novels. The importance of these characters within the totalitarian scheme of things is thus, clearly, not a function of who they truly are in themselves, but of the mythological-ideological role they play in the totalitarian grand narrative and of their position in the grand hierarchical design of the totalitarian state.

Before proceeding with the detailed examination of each of our two characters a few words might be in place here 
concerning the nature of their position vis-à-vis the societies over which they rule. To put it succinctly, the structural organisation of the totalitarian societies described by Orwell and Kadare is nothing if not hierarchical, and the great leader is the keystone which holds it all together. In Kadare's novel this hierarchy is materially symbolised by the mighty edifice of the Palace of Dreams whose respective stories represent the different strata that make-up the totalitarian body politic. In Orwell's novel the totalitarian hierarchy is more literally pictured in the way the people are regimented in mutually exclusive castes which stand on top of each-other in a rising order that eventually reaches its apex in the great leader. The very rigid social stratification which can be seen in the world of 1984, where the members of the so-called Inner Party live in a world entirely apart from the great majority of the inhabitants of Oceania (the Outer Party and the Proles), would lose its centre of gravity if it did not ultimately lead up to the figure of Big Brother that stands above all, and provides the whole totalitarian universe with a sense of direction.

\section{The Mythical Deification of Big Brother in Orwell's 1984}

As a matter of fact, the figure of Big Brother in Orwell's 1984 before serving as a general symbol for the deified tyrant of totalitarian societies, is reminiscent of certain historical personages, and more particularly of Stalin, the prototypical totalitarian dictator of modern times. The very portrait of Big Brother has clear physical parallels to Stalin - Big Brothers ubiquitous posters show "...the face of a man of about forty-five, with a heavy black moustache and ruggedly handsome features" (Orwell, 2003, p. 89), while his style of speaking, while giving speeches, is described as "at once military and pedantic" (Orwell, 2003, p. 130). The general impression of a marked resemblance between Big Brother and Stalin is confirmed by the depiction of the former's great rival Emmanuel Goldstein in terms that clearly associate him with the Stalin's chief political adversary from the ranks of the Old Bolsheviks, Leon Trotsky. ${ }^{1}$

This concretistic reading of Big Brother, however, though it clearly contributes to the contemporary dimension of 1984 as an anti-Soviet political satire, is clearly not on a par in order of importance with the universal significance that is conveyed by a more generally symbolical reading of the character. Big Brother is first and foremost a symbol of the totalitarian dictator that has been turned into a myth - as such the extent of his significance cannot be confined within the narrow limitations that are suggested by his likeness to particular historical personages. A symbolical reading of Big Brother indicates that, more than to any particular person from the world of history, his figure is akin to that of a mythical god that belongs to an essentially different realm from that of human beings.

Even his opposition to Goldstein, which, as we discussed above, at one level is clearly reminiscent of the historical struggle for political supremacy between Stalin and Trotsky in the post-revolutionary Soviet Union, at a deeper level can be seen as a symbolical representation of the archetypal conflict between God almighty and his demonic rival for the celestial throne. Not only the character of the antagonists themselves, but the very nature of the struggle between Big Brother and Goldstein seems to suggest such an interpretation. Thus, the conflict between the two is essentially different from that between the superpowers of this world - Oceania, Eurasia and Eastasia - which has its ups and downs and reversals of alliances. Big Brother's mighty clash with Goldstein, on the contrary, is not only uniformly implacable, but also seems to go on without end, strange enough though this may seem, given Goldstein' portrayal by the official propaganda in Oceania as a constant loser in all his efforts against Big Brother. Such a seeming paradox is easily dissolved if Goldstein is thought of not as a concrete person, an ordinary man made up of flesh and blood, who is vulnerable to pain and defeat, but as a supernatural being in possession of occult powers who, though he might never bring his devilish conspiracy to fruition, always remains there as a constant danger for the present order of things. Even the description of Goldstein's army as a "vast shadowy... network of conspirators dedicated to the overthrow of the State" (Orwell, 2003, p. 100) is suggestive of the hosts of demons and witches once thought to be led by Satan in a vast conspiracy against the kingdom of God.

Big Brother's divinity, in addition to what can be inferred about it from his exalted place in the totalitarian scheme of things and from the mythological conception of his antagonism to Goldstein, is, in fact, almost straightforwardly conveyed by the superhuman attributes that he is thought to posses. Like a perfect deity Big Brother is omnipresent and all-seeing. The eyes of his ubiquitous portrait which can be seen literally everywhere - among other places even "On coins, on stamps, on the covers of books, on banners, on posters, and on the wrappings of a cigarette Packet" (Orwell, 2003, p.

\footnotetext{
1 The character's very name, Emmanuel Goldstein, is clearly modelled on Trotsky's own proper name, Leon Bronstein. Even the physical description of Goldstein as having "... a lean Jewish face, with a great fuzzy aureole of white hair and a small goatee beard..." together with a "...long thin nose, near the end of which a pair of spectacles was perched..." (Orwell, 2003, p. 99) reminds one unmistakeably of the well-known physical features of Trotsky's portrait. More important than all this superficial likeness, however, is the fact that, ideologically speaking, the figure of Goldstein plays the same role in Big Brother's Oceania as that of Trotsky in Stalin's Soviet Union.
} 
111) - give people the impression that they have the almost magical power to penetrate right into their souls and find out what lies hidden in there. Likewise, the emblematic slogan "Big Brother is Watching You" (Orwell, 2003, p. 89), is clearly indicative of the fact that in Oceania the thought of having a private life, or even an inner self of one' own, that can be guarded from the intrusions of the Party is as absurd as that of trying to protect your sinful imaginings from the eye of an ever vigilant god. Over and above everything else indicative of Big Brother's status as an all-powerful otherworldly being is the quintessential mark of divinity that more than all other things distinguishes it from ordinary human nature - his perceived immortality. Grotesquely absurd as this may seem, the members of the Inner Party in Oceania take the immortality of their leader almost for granted. Thus, when a sceptical Winston Smith, asks their representative, O'Brien, whether Big Brother will one day actually die, the answer that he gets is an almost unbelievable "Of course not. How could he die?" (Orwell, 2003, p. 335).

In 1984 the mythical conception of Big Brother as a being that transcends the natural limitations of ordinary human beings is also expressed quite literally in the course of the long debate between Winston Smith and O'Brien, which is mainly conducted in the crisp analytical style typical of philosophical dialogues. At times, as a matter of fact, Obrien's explanations to Winston, especially when they concern Big Brother's unique mode of existence, which is unlike that of anybody else, seem to parody the sophistical style of philosophical paradoxes, and even to remind one of the speculations of scholastic theology on the nature of the deity (Orwell, 2003, pp. 334-335). Very straightforward, not only in their description of the role that Big Brother's myth plays in the Oceanic society, but also of the very process by which it is ideologically constructed, are certain passages in Goldstein's treatise on the nature of the political system in Oceania, which O'Brien gives to Winston Smith for reading. While expatiating on the similarities and differences of the three imperial superpowers that have carved up the whole world among themselves, Goldstein points out that "Everywhere there is the same pyramidal structure, the same worship of the semi-divine leader..." (Orwell, 2003, p. 273). In a rather different context within the same treatise, the reader encounters a very penetrating critical analysis of the whole mythology centred around the figure of Big Brother. The expository style of the passage matches its intent which is to divest the image of Big Brother from its mythological trappings and reveal the truth behind the ideological facade (it is even suggested that Big Brother might not even exist as an actual person!): "Nobody has ever seen Big Brother... We may reasonably be sure that he will never die... Big Brother is the guise in which the Party chooses to exhibit itself to the world. His function is to act as a focusing point for love, fear, and reverence, emotions which are more easily felt toward an individual than toward an organization" (Orwell, 2003, p. 284).

\section{The Mythical Conception of the Sultan in Kadare's The Palace of Dreams}

The Ottoman Sultan in Kadare's The Palace of Dreams closely resembles Orwell's Big Brother in 1984 in what he symbolically represents concerning the nature of political leadership in totalitarian societies. The very manner in which the figure of the Sultan is artistically portrayed in the novel suggests much about his mythical-ideological function in totalitarian discourse. If we were to adopt the terminology used by Prof. Bashkimi Kuçuku in his typological analysis of the characters found in the works of Kadare, we would describe the Sultan as an archetypal character "...who combines concrete human characteristics that can be associated with particular times and places, with more general universal features that seem to transcend temporal limitations..." (Kuçuku, 2005, p. 37 ). ${ }^{2}$ It is precisely these latter timeless features that lend to the character of the Sultan an almost mythical dimension, which, artistically speaking, is highly appropriate in expressing the role that the Sultan plays in the nightmarish totalitarian world described by Kadare.

It is not only the case that the Sultan, like Orwell's Big Brother, is presented only as the object of other people's communication, without ever making a physical appearance on the stage of the action, but also that the reader gets to know almost next to nothing about his individual human characteristics - in fact, Kadare omits to mention even his proper name. The only seemingly personal characteristic of the Sultan is his proverbial jealousy (rumour has it that he is jealous of the powerful Albanian clan of the Quprilis because of their epic). Even that, however, has more to do with the Sultanate in general, than with the individual person who happens to be the Sultan at a particular time. The jealousy of the Sultans for the epic of the Quprilis has been passed down from generation to generation in the Ottoman ruling family - it is even thought to be the main reason, albeit a never openly declared one, of the frequent blows it has delivered to the Albanian family along the centuries (Kadare, 1993, p. 66). Jealousy, thus, seems to be a permanent timeless feature of this mythical impersonal being, despite the individual variations among its successive incarnations in time and place.

Furthermore, even the feeling of jealousy in itself, a petty human emotion though it might seem at first sight, does not in fact detract from the Sultan's status as a more than human being. On the contrary, jealousy is one of the archetypal

\footnotetext{
2 The translation from the Albanian original is mine.
} 
characteristics of the gods: the Greek gods are portrayed as acutely jealous, while even the one God of the Jews is famously referred to in the Hebrew Bible as "a jealous god". The very reason why the Ottoman Sultan feels jealous of the Quprilis suggests a mythical connotation as it is directly related to the world of myths and legends: the Sultan's feeling for the Quprilis is rooted in their having a place of honour in the mythical universe of the Balkan epics, while he, himself, is conspicuously absent from their legendary heroic pantheon.

The conception that other characters in The Palace of Dreams have of the Sultan demonstrates that in Kadare's world he serves the same function as Big Brother in Orwell's 1984. In other words, the Ottoman Sultan stands as the symbol of the deified autocratic ruler who is looked upon as the ultimate source of order and wisdom in the totalitarian world, though such ideas are more felt than distinctly understood by his subjects. As a matter of fact, everything that happens in The Palace of Dreams seems, in the final analysis, to be the ultimate product of the Sultan's inscrutable ways. Though the Sultan's unseen presence is felt behind everything, his exact plans and intentions, however, remain shrouded in secrecy. With the sole exception of the proverbial jealousy attributed to the Sultanate as such, the basic urges that prompt the Sultan to action are never analysed or even mentioned in the course of the novel. The mystery that surrounds the figure of the Sultan invests it, in fact, with the godly halo of the inscrutable and the ineffable. Like a true god he is mentally experienced as belonging to a different realm of existence from that where ordinary mortals, including the ruling caste of the Empire, live their mundane lives. The almost impenetrable silence around the Sultan suggests a conception of him as a superhuman being who cannot be understood and explained by the common categories of thinking. From the unreachable heights of his mighty authority the Sultan watches over everybody, distributing favours and handing out punishments according to an unfathomable logic that seems quite arbitrary to ordinary mortals (unpredictability is one of the key attributes of absolute power). To the earthly observer it remains an unexplainable mystery whether the sudden changes that seem to mark the course of actions followed by the Sultan are the expression of his unstable humours, or if they reflect a more thorough and elevated perspective of things, such as cannot be shared by other people. Both alternatives, however, are equally suggestive of the same absolute superhuman power like that of a mythical god.

What we said above about the mythical conception of the Sultan in The Palace of Dreams, could well be illustrated by Kurt Quprili's comparison of him to Mount Vesuvius. Conversing about the ups and downs that have long marked the fortunes of the Quprilis in the Ottoman state, Kurt makes the following striking analogy: "We Quprilis, we're like people living at the foot of Vesuvius. Just as they are covered with ashes when the volcano erupts, so are we every so often struck down by the Sovereign in whose shadow we live. And just as the others resume their ordinary lives afterword, cultivating the soil that is as fertile as it is dangerous, so we, despite the blows the Sovereign rains on us, go on living in his shade and serving him faithfully" (Kadare, 1993, p. 59). The mythical connotations of this short passage are very rich and striking indeed. For one thing, Mount Vesuvius, as the volcano whose eruption caused the destruction of the ancient Roman city of Pompeii, is distinctly associated with the world of pagan antiquity - the classical age of mythology in the Western tradition. Kurt's description of the Sultan as one who "rains" down "blows" on people, suggests that his person is thought of and talked about in terms which are very similar to those commonly used to describe the elemental forces of nature or even the gods themselves (to give but one example, the Greek god Zeus was commonly pictured by the ancients as hurling thunderbolts on his enemies). On the other hand, even the comparison of the Sultan's bountiful shade with the fertility of the soil around Vesuvius suggests the close relationship between the idea of power and that of material plenty in primitive mythical thought. ${ }^{3}$ Lastly the very appellation of the Sultan as "the Sovereign" connotes the fact that his right to dominion, like that of a god, inheres in his own person, and should not be thought of as needing justification in terms of social contracts or other mundane political concepts.

\section{Conclusion}

In conclusion, we should like to reiterate that, as the above analysis of the characters of Big Brother and the Sultan in our view shows, the great leader in totalitarian societies is thought of in mythical terms which turn him into an almost god-like figure that gives meaning, unity and a sense of direction to the whole totalitarian universe. Besides their similar features and the common significance that their personae have within the totalitarian societies described by the two writers, Orwell's Big Brother and Kadare's Sultan also share a marked resemblance as to the manner in which they are artistically made up as characters. Neither Big Brother, nor the Sultan, though their unseen presence looms large behind the scenes

\footnotetext{
${ }^{3}$ Such a relationship is famously analysed by Elias Cannetti in his classical Crowds and Power. One of the many examples that he gives to support this idea is that of the king of Jukun in Nigeria who was expected by his people not so much to lead them into battle or to rule them wisely, but rather was regarded as "a living reservoir of those forces which make the earth fertile and seed flourish and thus bring life and wellbeing to men" (Cannetti, 1981, p. 413).
} 
as a constant background to the actual action of the novels, ever physically appear on stage. In 1984, Winston doubts even whether Big Brother is actually a real person or only a chimerical creature made up by those in power in order to scare the people into submission, while in The Palace of Dreams the Sultan is not even once referred to by his proper name. On the other hand, the unseen leader himself, quite unlike everybody else, not only manages to see everything from the elevated vantage point that his position affords him ("Big Brother is watching you!" is the emblematic slogan that most typically represents the new order of life in Orwell's dystopian world), but can strike quite arbitrarily on anyone (the Ottoman Sultan in The Palace of Dreams acts towards the powerful clan of the Quprilis with a quite unpredictable logic of his own), just like a god who belongs to an altogether different plane of existence from that of ordinary mortals. These typical godly attributes invest the figure of the totalitarian dictator with a superhuman halo that makes him transcend the usual limitations which bind more earthly characters to a particular time and place. Such characters, then, have an archetypal dimension that universalizes their significance beyond their association with particular historical personages.

\section{References}

Bassnett, S. (1993). Comparative Literature - A Critical Introduction. Oxford: Blackwell.

Bowker, G. (2003). George Orwell. London: Palgrave Macmillan.

Canetti, E. (1981). Crowds and Power. (Carol Stewart, Trans.). New York: Continuum Publishing Corporation.

Crick, B. (1980). George Orwell: a Life. Boston: Little Brown.

Eliade, M. (1963). Myth and Reality. (Willard R. Trask, Trans.). New York: Harper \& Row.

Kadare, I. (1993) The Palace of Dreams. (Barbara Bray, Trans.). New York: Arcade Publishing.

Kadare, I. (1999). Pallati i Ëndrrave. Tiranë: Onufri.

Kuçuku, B. (2005). Kadare në gjuhët e botës. Tiranë: Onufri.

Norris, C. (Ed.). (1987). Inside the Myth - Orwell - Views from the Left. London: Lawrence and Wishart Ltd.

Orwell, G. (2003). Animal Farm and 1984. Orlando: Harcourt Inc.

Rodden, J. (Ed.). (2007). The Cambridge Companion to George Orwell. Cambridge: Cambridge University Press.

Sinani, S. (2005). Një dosje për Kadarenë. Tiranë: OMSCA-1.

Sinani, S. (2011). Letërsia në totalitarizëm dhe "Dossier K". Tiranë: Naimi. 